\title{
THE CHARACTERISTICS OF THORACIC DUCT LYMPH IN MAN
}

\author{
By H. R. BIERMAN, R. L. BYRON, JR., K. H. KELLY, R. S. GILFILLAN, L. P. WHITE, \\ N. E. FREEMAN, aNd N. L. PETRAKIS, with THE TEChNICAL ASSISTANCE of \\ GRACE SINGER AND FAUNO CORDES \\ (From the Laboratory of Experimental Oncology, National Cancer Institute, National Institutes \\ of Health, Public Health Service, Federal Security Agency; the Department of \\ Medicine and Cancer Research Institute, University of California School of \\ Medicine; and the Department of Surgery, University of California \\ School of Medicine, San Francisco, Cal.)
}

(Submitted for publication January 17, 1953 ; accepted April 4, 1953)

The thoracic duct is generally accepted as the major pathway of lymphocytes enroute to the circulating blood $(1,2,3)$, accounting for approximately 70 per cent of all the lymphocytes in the peripheral blood. The remainder of the lymphocytes are said to enter the blood directly via the lymph from other sites (2). Reliable information concerning the hematologic content of lymph in the thoracic duct of man has been fragmentary and limited to chance observations in few patients (4).

The thoracic duct lymph is reported to flow from one to six hours after death $(5,6)$. Consequently, an attempt was made to study the cellular components of human lymph obtained by cannulation of the thoracic duct within one hour after death and then in vivo if a feasible technic could be developed (7). Volumetric measurements of the flow of lymph in addition would permit an estimation of the number of cells delivered per unit time into the peripheral circulation via the thoracic duct (8). Since at least two thoracic ducts are present in man in addition to innumerable other lymph-to-blood connections, it was realized that these anatomical considerations seriously limited the interpretation of single samples. Consequently cannulation of the major thoracic duct for continuous drainage over prolonged periods was undertaken.

\section{PATIENTS AND METHODS}

The thoracic ducts of 16 cadavers were isolated within one hour after death. Satisfactory flow of lymph fluid was obtained in 11 of these necropsy cases, 10 of whom had a form of leukemia. The hematologic findings were contrary to that expected from a review of the literature. Because of a valid criticism of any interpretation derived from post mortem material, the study was extended to living man (Figure 1).

Studies were performed on 10 patients, all of whom were far advanced in the course of their neoplastic disease, and all of whom volunteered as subjects after being informed of the proposed study. Four patients had leukemia, and six had other malignancies. Four ounces of milk and cream were given orally one-half hour prior to the procedure to aid in the identification of the duct. Polythene tubing, 2 to $3 \mathrm{~mm}$. in external diameter, was introduced 3 to $5 \mathrm{~cm}$. into the proximal segment of the thoracic duct pointing retrograde as it approached the left internal jugular-subclavian vein junction. The segment of the duct emptying into the venous junction was ligated. The polythene tubing pointing medially and inferiorly was securely tied in place after flow was established. The skin was closed with interrupted sutures without approximating the deeper layers. The tubing was fixed by sutures within the edges of the wound as it was closed.

The lymph was collected by gravity drip into sterile, silicone-lined glass containers. Heparin was employed exclusively as the anticoagulant. Samples for hematologic or chemical determinations were collected as separate fresh specimens. All counts and determinations were done as promptly as possible employing NBS certified hemocytometers and Trenner automatic filling pipets. In counts between 5,000 to 10,000 per cu. ml., counting all nine squares on each of two chambers from a single pipet, the 70 per cent confidence limits of the value obtained were \pm 8.5 per cent. Peripheral venous blood was taken simultaneously for comparison. In the patients studied post mortem, blood for comparison had been obtained either just before death or by cardiac puncture after death.

In five instances, the thoracic duct was outlined in vivo by the retrograde introduction of Diodrast or Thorotrast (Figures 2A, B, C, D).

Whole blood or plasma was employed to replace the draining lymph, usually volume for volume. After the period of the lymph drainage was completed, the tubing was sealed and the lymph within was allowed to clot. The tube was uneventfully withdrawn 3 to 10 days later.

\section{RESULTS}

Studies post mortem. Attempts to locate the thoracic duct post mortem were uniformly unsuccessful unless half cream-half milk had been ingested 3 to 24 hours before cannulation. Satisfactory lymph flow was obtained in 11 patients, 10 
of whom had leukemia (Table I). In eight patients, the blood leukocyte level exceeded the leukocyte level of the thoracic duct lymph; in two patients the reverse was found to be true. The leukocyte counts were the same in the lymph and blood of the remaining patient.

Studies in vivo. The thoracic duct was clearly distinguishable in vivo when the cream and milk comfort after the first 24 or 48 hours. Delayed healing of the wound occurred in an area which had been repeatedly treated with intensive $\mathrm{X}$-radiation in a single patient (KIN) who had advanced Hodgkin's disease. No evidence of a chylous fistula appeared in any case. One patient experienced transient syncope during the introduction of 70 per cent Diodrast into the thoracic duct al-

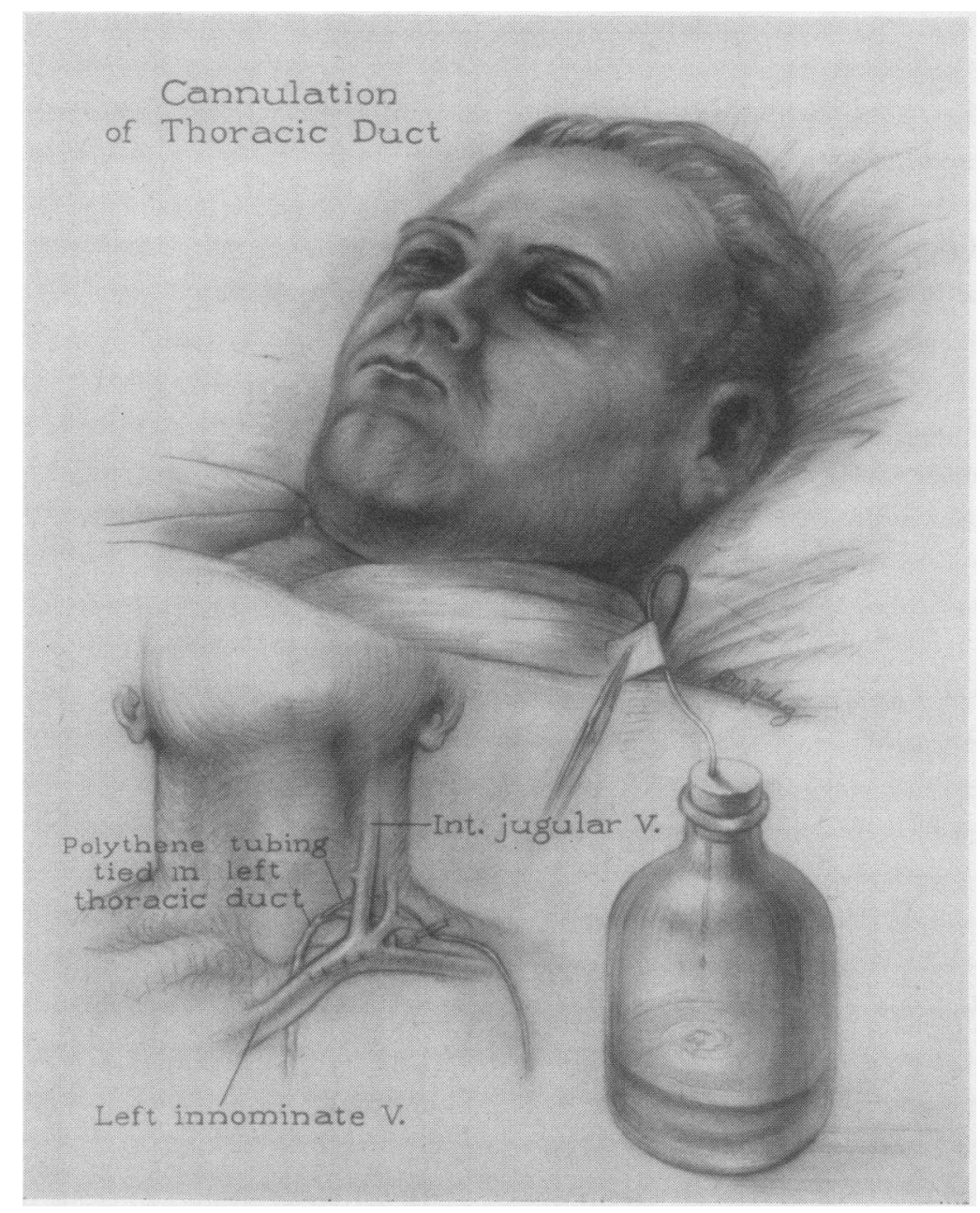

Fig. 1. Cannulation of the Thoracic Duct

The lymph is collected in sterile containers by gravity drip.

were given 15 to 30 minutes before surgical exploration of the duct area. Thoracic duct lymph was obtained for continuous periods of 2 to 13 days in 10 patients (Table II, Figure 3). The polythene tube caused no untoward reaction during or after the period of drainage and did not seriously impair motion of the head or neck or cause dis- though intravenous testing had shown no sensitivity.

Appearance and flow characteristics. The lymph of the non-leukemic and leukemic patients had an opalescent appearance resembling skimmed milk, varying between a thick creamy and a thin watery consistency. Cream appeared within 10 to 20 


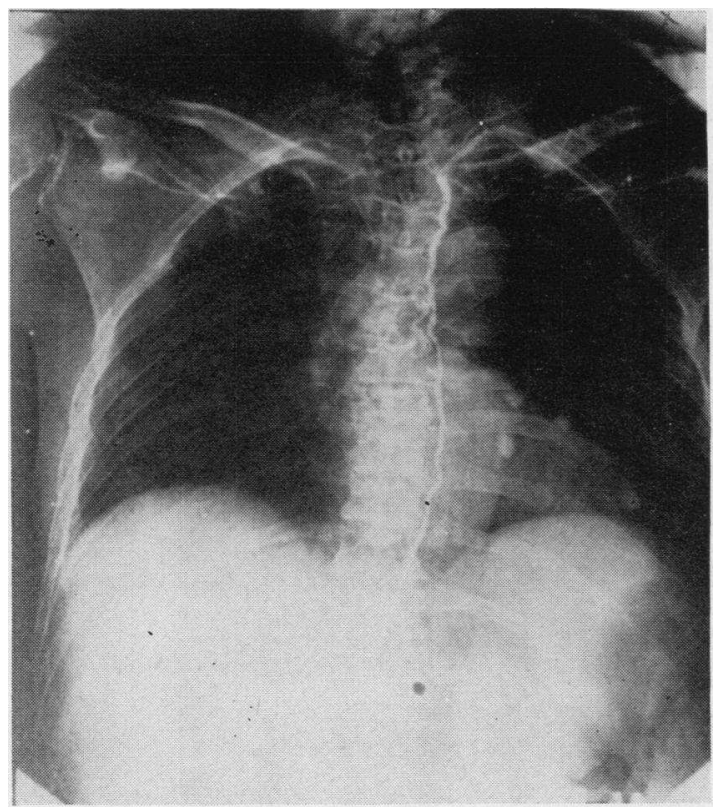

A

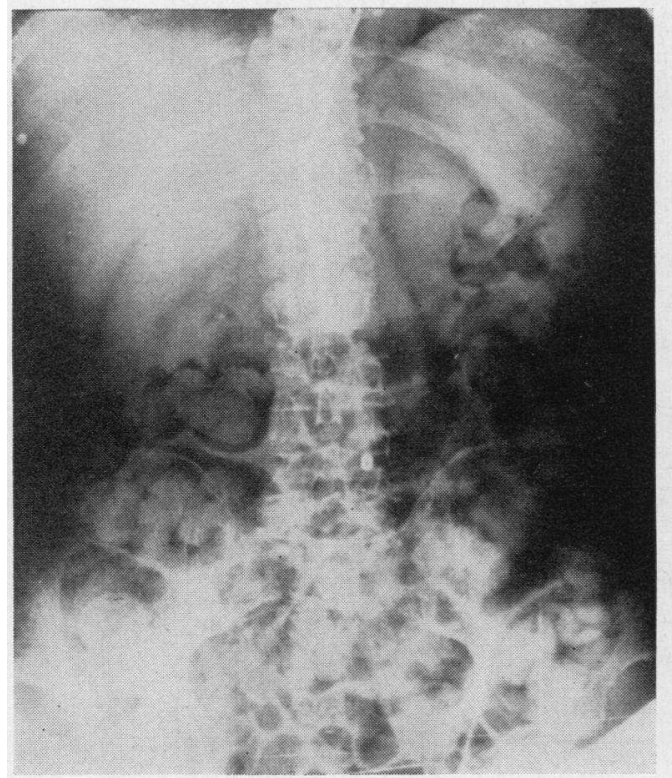

C

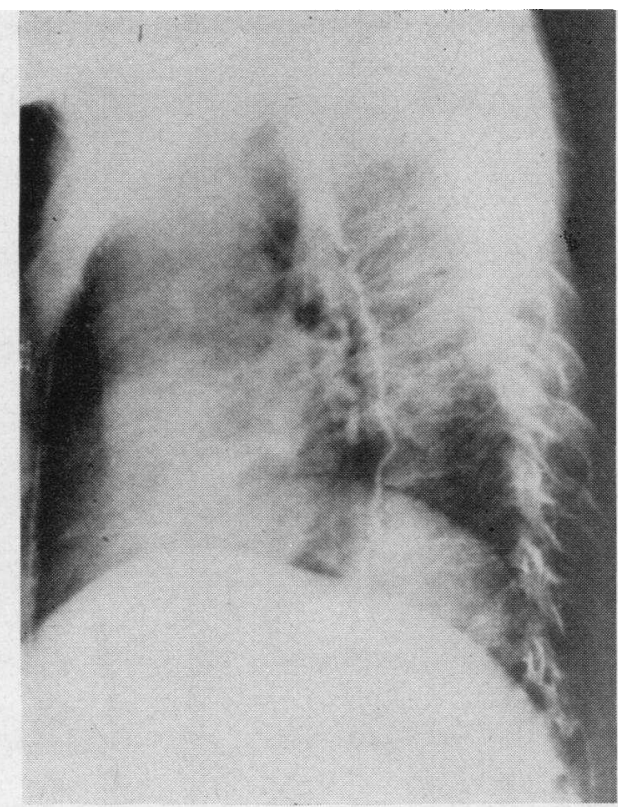

B

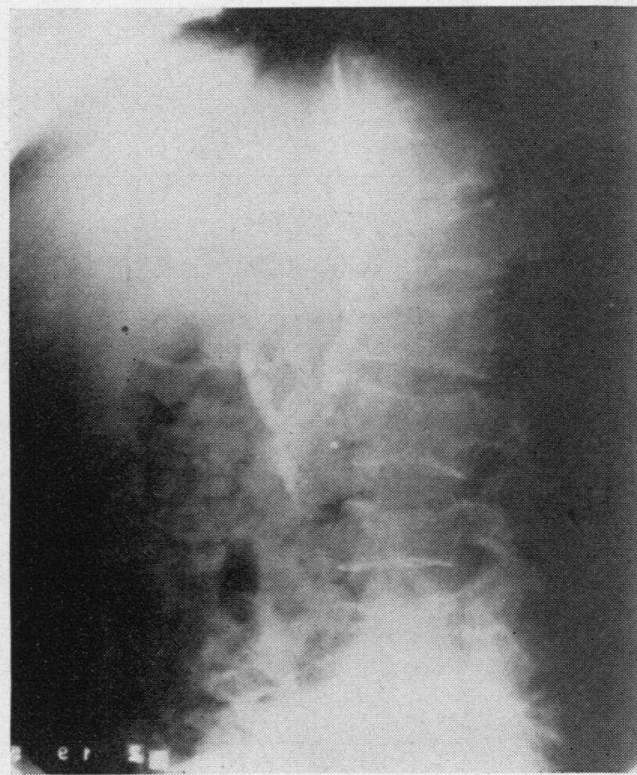

D

FIG. 2

A. Outline of thoracic duct in thorax following retrograde introduction of 75 per cent Diodrast.

B. Lateral view.

C. Anterior view of abdominal portion of the thoracic duct. The marker " $O$ " is at the umbilicus.

D. Lateral view of abdominal portion. Note filling anteriorly of what is presumed to be mesenteric lymphatics. 
TABLE I

Hematological data of thoracic duct lymph of eleven patients obtained at post mortem compared with venous blood

\begin{tabular}{|c|c|c|c|c|c|c|c|c|c|c|c|c|c|}
\hline \multirow[t]{2}{*}{$\begin{array}{c}\text { Name, Sex, Age } \\
\text { Diagnosis }\end{array}$} & \multicolumn{2}{|c|}{$\begin{array}{l}\text { LIB F } 3 \\
\text { Lymphatic } \\
\text { leukemia }\end{array}$} & \multicolumn{2}{|c|}{$\begin{array}{c}\text { LEF F } 11 \\
\text { Lymphatic } \\
\text { leukemia }\end{array}$} & \multicolumn{2}{|c|}{$\begin{array}{c}\text { CUM M } 11 \\
\text { Lymphatic } \\
\text { leukemia }\end{array}$} & \multicolumn{2}{|c|}{$\begin{array}{c}\text { DEM M } 19 \\
\substack{\text { Lymphatic } \\
\text { leukemia }}\end{array}$} & \multicolumn{2}{|c|}{$\begin{array}{c}\text { KAN F } 35 \\
\substack{\text { Lymphatic } \\
\text { leukemia }}\end{array}$} & \multicolumn{2}{|c|}{$\begin{array}{c}\text { JOH M } 51 \\
\substack{\text { Lymphatic } \\
\text { leukemia }}\end{array}$} & \\
\hline & Lymph & Blood & Lymph & Blood & Lymph & Blood & Lymph & Blood & Lymph & Blood & Lymph & Blood & \\
\hline Sample site & $\begin{array}{l}\text { Thoracic } \\
\text { duct }\end{array}$ & $\begin{array}{l}\text { Finger, } \\
1 \text { hr.* }\end{array}$ & $\begin{array}{l}\text { Thoracic } \\
\text { duct }\end{array}$ & $\begin{array}{l}\text { Finger, } \\
1 \text { hr.* }\end{array}$ & $\begin{array}{l}\text { Thoracic } \\
\text { duct }\end{array}$ & Cardiac & $\begin{array}{l}\text { Thoracic } \\
\text { duct }\end{array}$ & Cardiac & $\begin{array}{l}\text { Thoracic } \\
\text { duct }\end{array}$ & Cardiac & $\begin{array}{l}\text { Thoracic } \\
\text { duct }\end{array}$ & $\begin{array}{l}\text { Vein, } \\
5 \text { hrs.* }\end{array}$ & $\begin{array}{l}\text { Peri- } \\
\text { cardial } \\
\text { fluid }\end{array}$ \\
\hline R BC & 650,000 & & 460,000 & $\begin{array}{l}\text { Hbg., } \\
5.8 \mathrm{gms} .\end{array}$ & 580,000 & $1,900,000$ & 100,000 & $1,250,000$ & 400,000 & $1,160,000$ & 770,000 & $2,680,000$ & 30,000 \\
\hline Platelets & & & 80,000 & & & & & 130,000 & 30,000 & 40,000 & & 60,000 & \\
\hline WBC & 50,200 & 50,000 & 241,000 & 322,000 & 100 & 800 & 6,550 & 330,000 & 82,000 & 500,000 & 3,600 & 800 & 1,900 \\
\hline $\begin{array}{l}\text { Differentials in } \\
\text { per cent } \\
\text { PMN } \\
\text { Meta } \\
\text { Myl }\end{array}$ & & 1 & & & 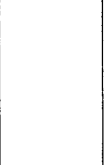 & 4 seen & & 2 & 6 & $\begin{array}{l}5 \\
2 \\
3\end{array}$ & & 76 & \\
\hline $\begin{array}{l}\text { Lymphs, small } \\
\qquad \text { large } \\
\text { Others }\end{array}$ & $\begin{array}{l}80 \\
20\end{array}$ & 99 & $\begin{array}{l}80 \\
20\end{array}$ & $\begin{array}{l}80 \\
20\end{array}$ & $\begin{array}{l}20 \text { seen } \\
1 \text { normo- } \\
\text { blast }\end{array}$ & $\begin{array}{l}1 \text { normo- } \\
\text { blast }\end{array}$ & $\begin{array}{r}94 \\
6\end{array}$ & $\begin{array}{l}13 \\
85\end{array}$ & $\begin{array}{r}80 \\
+\quad 58\end{array}$ & $\begin{array}{l}32 \\
58\end{array}$ & 100 & $\begin{array}{l}2 \text { mono- } \\
\text { cytes }\end{array}$ & \\
\hline
\end{tabular}

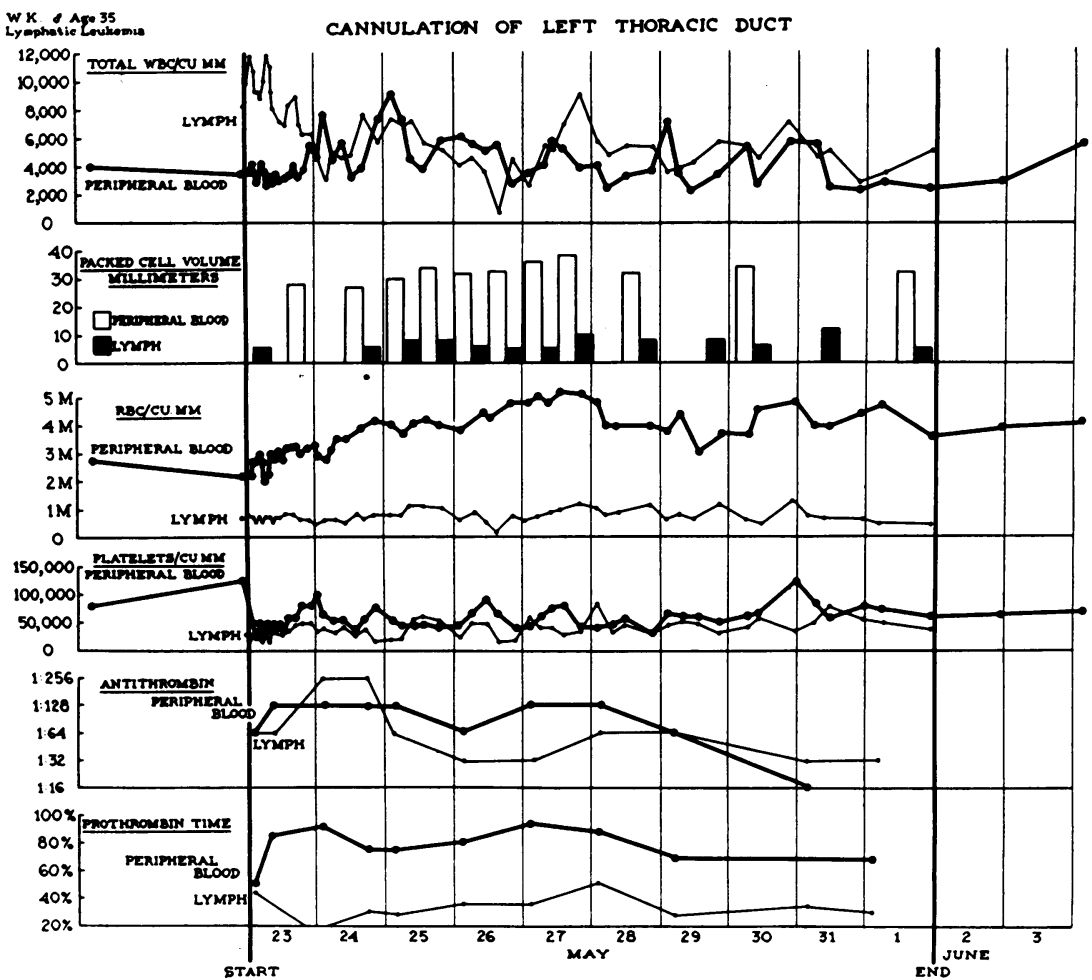

Fig. 3. Hematological Data during a Representative Study on KiR, 35year-old Man with Subleukemic Lymphatic Leukemia

Note that the blood and lymph leukocyte counts approximate one another closely except for the first 24 hours. 
TABLE I-Continued

\begin{tabular}{|c|c|c|c|c|c|c|c|c|c|c|}
\hline \multirow[t]{2}{*}{$\begin{array}{c}\text { Name, Sex, Age } \\
\text { Diagnosis }\end{array}$} & \multicolumn{2}{|c|}{$\begin{array}{c}\text { PIT } \quad \text { M } 66 \\
\text { Lymphatic leukemia }\end{array}$} & \multicolumn{2}{|c|}{$\begin{array}{c}\text { VAL } \quad F \quad 68 \\
\text { Lymphatic leukemia }\end{array}$} & \multicolumn{2}{|c|}{$\begin{array}{c}\text { SPI } \quad \text { M } 47 \\
\text { Myelogenous leukemia }\end{array}$} & \multicolumn{2}{|c|}{$\begin{array}{c}\text { COO M } 49 \\
\text { Myelogenous leukemia }\end{array}$} & \multicolumn{2}{|c|}{ 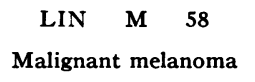 } \\
\hline & Lymph & Blood & Lymph & Blood & Lymph & Blood & Lymph & Blood & Lymph & Blood \\
\hline Sample site & $\begin{array}{l}\text { Thoracic } \\
\text { duct }\end{array}$ & Ear, 5 hrs.* & $\begin{array}{l}\text { Thoracic } \\
\text { duct }\end{array}$ & $\begin{array}{l}\text { Finger, } \\
1 \mathrm{hr} . *\end{array}$ & $\begin{array}{l}\text { Thoracic } \\
\text { duct }\end{array}$ & Cardiac & $\begin{array}{l}\text { Thoracic } \\
\text { duct }\end{array}$ & $\begin{array}{l}\text { Ear, } \\
\text { 2 days* }\end{array}$ & $\begin{array}{l}\text { Thoracic } \\
\text { duct }\end{array}$ & Ear, 4 hrs.* \\
\hline $\mathrm{RBC}$ & 240,000 & $\begin{array}{l}\text { Hbg., } \\
8.0 \text { gms. }\end{array}$ & 350,000 & $3,260,000$ & 280,000 & $1,580,000$ & 740,000 & $\begin{array}{l}\text { Hbg., } \\
11.8 \text { gms. }\end{array}$ & 36,000 & $2,130,000$ \\
\hline Platelets & & 80,000 & 10,000 & 55,000 & 10,000 & 10,000 & & & & 100,000 \\
\hline WBC & 55,000 & 289,000 & 35,600 & 381,000 & $3,000 \dagger$ & 403,000 & 80,000 & 18,450 & 2,700 & 10,500 \\
\hline $\begin{array}{l}\text { Differentials in } \\
\text { per cent } \\
\text { PMN }\end{array}$ & & & 2 & & 70 & 31 & 2 & 13 & $5 \ddagger$ & 86 \\
\hline Meta & & & & 2 & & & & 31 & & 2 \\
\hline Myl & & & 1 & 1 & & 68 & 38 & 16 & & 1 \\
\hline $\begin{array}{r}\text { Lymphs, small } \\
\text { large }\end{array}$ & 100 & 100 & $\begin{array}{r}93 \\
4\end{array}$ & $\begin{array}{r}95 \\
2\end{array}$ & 30 & 1 & 60 & 34 & $\begin{array}{l}3 \\
2\end{array}$ & 11 \\
\hline Others & & & & & & & & $\begin{array}{l}\text { PMB, } 3 \\
\text { PME, } 3\end{array}$ & & \\
\hline
\end{tabular}

* Before death.

† One cc. sample obtained diluted by $0.2 \mathrm{cc}$. of heparin. Counts were not corrected for this dilution.

$\ddagger$ Ten cells were differentiated. The remainder of the leukocytes showed degenerative changes. The erythrocytes appeared unaltered.

minutes after oral ingestion. In the leukemic patients, the lymph was more often blood-tinged, related to its content of erythrocytes (Table II).

The flow of lymph varied from 300 to $2,800 \mathrm{ml}$. of fluid per 24 hours (Figure 4). Free flow of lymph was obtained and measured accurately in six patients in whom the lymph content of leukocytes was also determined, thereby permitting an estimation of the number of cells passing through the thoracic duct ostensibly for delivery into the peripheral circulation (Table III). Cannulation of the right thoracic duct in patient ELM 36 hours

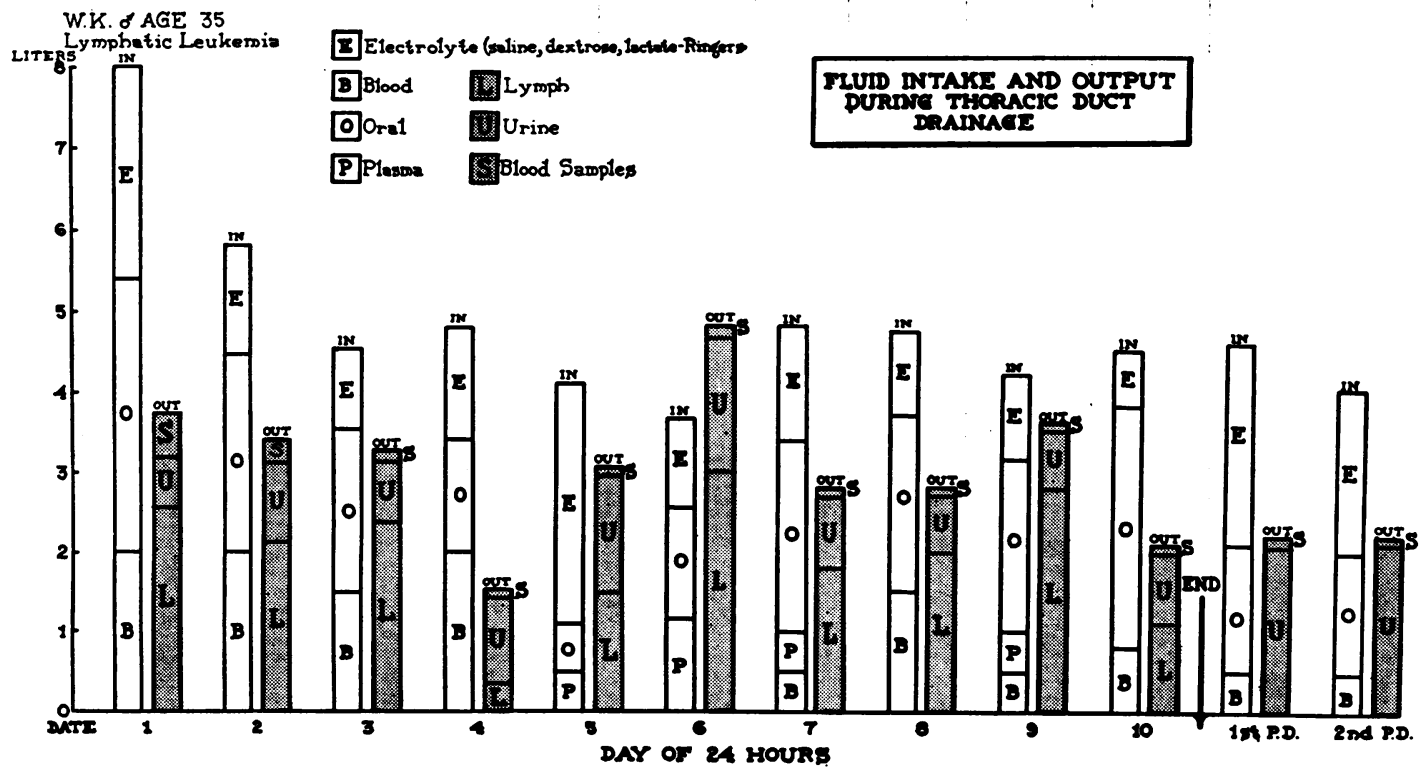

Fig. 4. Data on Lymph Flow and Fluid Replacement during Study on Patient KiR The fear of significant fluid loss failed to materialize under this regimen of replacement. 
TABLE II

Hematological data of thoracic duct lymph and venous blood on 10 patients obtained in vivo

\begin{tabular}{|c|c|c|c|c|c|c|c|c|c|c|}
\hline \multirow[t]{2}{*}{$\begin{array}{l}\text { Name, Sex, Age } \\
\text { Diagnosis } \\
\text { Drainage period }\end{array}$} & \multicolumn{2}{|c|}{$\begin{array}{c}\text { Lymphatic leukemia } \\
2 \text { days }\end{array}$} & \multicolumn{2}{|c|}{$\begin{array}{c}\text { Lymphatic leukemia } \\
3 \text { days }\end{array}$} & \multicolumn{2}{|c|}{$\begin{array}{c}\text { Subleukemic } \\
\text { lymphatic leukemia } \\
11 \text { days }\end{array}$} & \multicolumn{2}{|c|}{$\begin{array}{c}\text { Myeloblastic leukemia } \\
\text { with chloroma } \\
4 \text { days }\end{array}$} & \multicolumn{2}{|c|}{$\begin{array}{l}\text { Multiple myeloma } \\
13 \text { days }\end{array}$} \\
\hline & $\begin{array}{l}\text { Highest } \\
\text { lymph } \\
\text { count }\end{array}$ & $\begin{array}{l}\text { Corre- } \\
\text { sponding } \\
\text { blood }\end{array}$ & $\begin{array}{l}\text { Highest } \\
\text { lymph } \\
\text { count }\end{array}$ & $\begin{array}{l}\text { Corre- } \\
\text { sponding } \\
\text { blood }\end{array}$ & $\begin{array}{l}\text { Highest } \\
\text { lymph } \\
\text { count }\end{array}$ & $\begin{array}{l}\text { Corre- } \\
\text { sponding } \\
\text { blood }\end{array}$ & $\begin{array}{l}\text { Highest } \\
\text { lymph } \\
\text { count }\end{array}$ & $\begin{array}{l}\text { Corre- } \\
\text { sponding } \\
\text { blood }\end{array}$ & $\begin{array}{c}\text { Highest } \\
\text { lymph } \\
\text { count }\end{array}$ & $\begin{array}{l}\text { Corre- } \\
\text { sponding } \\
\text { blood }\end{array}$ \\
\hline \multirow[t]{2}{*}{$\begin{array}{l}\text { RBC } \\
\text { Platelets } \\
\text { WBC } \\
\text { Differentials in per cent: } \\
\text { PMN } \\
\text { Meta } \\
\text { Myl } \\
\text { PME } \\
\text { Lymphs: } \\
\text { small } \\
\text { young } \\
\text { Mono } \\
\text { Others }\end{array}$} & $\begin{array}{r}156,000 \\
4,500 \\
6,200\end{array}$ & $\begin{array}{r}2,690,000 \\
25,000 \\
49,000\end{array}$ & $\begin{array}{r}99,000 \\
4,500 \\
40,600\end{array}$ & $\begin{array}{r}4,070,000 \\
95,000 \\
166,000 \\
11 \\
\\
5 \\
83 \\
1\end{array}$ & $\begin{array}{r}790,000 \\
25,000 \\
11,900\end{array}$ & $\begin{array}{r}2,280,000 \\
25,000 \\
2,800 \\
11 \\
\\
1 \\
85 \\
3\end{array}$ & $\begin{array}{r}450,000 \\
15,000 \\
27,200 \\
1\end{array}$ & $\begin{array}{r}2,390,000 \\
130,000 \\
67,000 \\
12 \\
12 \\
2 \\
44\end{array}$ & $\begin{array}{c}98 \\
\text { Plasma cell, } 1\end{array}$ & $\begin{array}{r}3,950,000 \\
125,000 \\
2,600 \\
67 \\
5 \\
16 \\
11 \\
\text { РМ }, 1\end{array}$ \\
\hline & $\begin{array}{l}\text { Lowest } \\
\text { lymph } \\
\text { count }\end{array}$ & $\begin{array}{l}\text { Corre- } \\
\text { sponding } \\
\text { blood }\end{array}$ & $\begin{array}{l}\text { Lowest } \\
\text { lymph } \\
\text { count }\end{array}$ & $\begin{array}{l}\text { Corre- } \\
\text { sponding } \\
\text { blood }\end{array}$ & $\begin{array}{l}\text { Lowest } \\
\text { lymph } \\
\text { count }\end{array}$ & $\begin{array}{l}\text { Corre- } \\
\text { sponding } \\
\text { blood }\end{array}$ & $\begin{array}{l}\text { Lowest } \\
\text { lymph } \\
\text { count }\end{array}$ & $\begin{array}{l}\text { Corre- } \\
\text { sponding } \\
\text { blood }\end{array}$ & $\begin{array}{l}\text { Lowest } \\
\text { lymph } \\
\text { count }\end{array}$ & $\begin{array}{l}\text { Corre- } \\
\text { sponding } \\
\text { blood }\end{array}$ \\
\hline \multirow[t]{2}{*}{$\begin{array}{l}\text { RBC } \\
\text { Platelets } \\
\text { WBC } \\
\text { Differentials in per cent: } \\
\text { PMN } \\
\text { Meta } \\
\text { Myl } \\
\text { PME } \\
\text { Lymphs: } \\
\text { small } \\
\text { young } \\
\text { Mono } \\
\text { Others }\end{array}$} & $\begin{array}{r}174,000 \\
2,500 \\
3,900\end{array}$ & $\begin{array}{r}2,380,000 \\
25,000 \\
39,000\end{array}$ & $\begin{array}{r}6,300 \\
4,000 \\
17,800\end{array}$ & $\begin{array}{r}3,000,000 \\
90,000 \\
121,000 \\
2\end{array}$ & $\begin{array}{r}150,000 \\
5,000 \\
600 \\
1\end{array}$ & $\begin{array}{r}4,390,000 \\
60,000 \\
4,200 \\
16\end{array}$ & $\begin{array}{r}100,000 \\
20,000 \\
10,000 \\
\\
1 \\
\\
\\
\\
93 \\
6\end{array}$ & $\begin{array}{r}2,080,000 \\
110,000 \\
42,100 \\
\\
10 \\
2 \\
2 \\
1 \\
38 \\
25 \\
2\end{array}$ & $\begin{array}{r}5,000 \\
5,000 \\
210\end{array}$ & $\begin{array}{r}4,030,000 \\
85,000 \\
1,900 \\
64\end{array}$ \\
\hline & $\begin{array}{l}\text { Corre- } \\
\text { sponding } \\
\text { lymph }\end{array}$ & $\begin{array}{l}\text { Highest } \\
\text { blood } \\
\text { count }\end{array}$ & $\begin{array}{l}\text { Corre- } \\
\text { sponding } \\
\text { lymph }\end{array}$ & $\begin{array}{l}\text { Highest } \\
\text { blood } \\
\text { count }\end{array}$ & $\begin{array}{l}\text { Corre- } \\
\text { sponding } \\
\text { lymph }\end{array}$ & $\begin{array}{l}\text { Highest } \\
\text { blood } \\
\text { count }\end{array}$ & $\begin{array}{l}\text { Corre- } \\
\text { sponding } \\
\text { lymph }\end{array}$ & $\begin{array}{l}\text { Highest } \\
\text { blood } \\
\text { count }\end{array}$ & $\begin{array}{l}\text { Corre- } \\
\text { sponding } \\
\text { lymph }\end{array}$ & $\begin{array}{l}\text { Highest } \\
\text { blood } \\
\text { count }\end{array}$ \\
\hline \multirow[t]{2}{*}{$\begin{array}{l}\text { RBC } \\
\text { Platelets } \\
\text { WBC } \\
\text { Differentials in per cent : } \\
\text { PMN } \\
\text { Meta } \\
\text { Myl } \\
\text { PME } \\
\text { Lymphs: } \\
\text { small } \\
\text { young } \\
\text { Mono } \\
\text { Others }\end{array}$} & $\begin{array}{r}156,000 \\
4,500 \\
6,200\end{array}$ & $\begin{array}{r}2,690,000 \\
25,000 \\
49,000\end{array}$ & $\begin{array}{r}99,000 \\
4,500 \\
40,600\end{array}$ & $\begin{array}{r}4,070,000 \\
95,000 \\
166,000 \\
11 \\
\\
5 \\
83 \\
1\end{array}$ & $\begin{array}{r}895,000 \\
25,000 \\
6,900 \\
1\end{array}$ & $\begin{array}{r}3,720,000 \\
45,000 \\
8,500 \\
13\end{array}$ & $\begin{array}{r}450,000 \\
15,000 \\
27,200 \\
1\end{array}$ & $\begin{array}{r}2,390,000 \\
130,000 \\
67,000 \\
12 \\
2 \\
44\end{array}$ & $\begin{array}{r}35,000 \\
10,000 \\
1,200\end{array}$ & 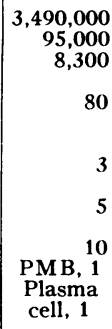 \\
\hline & $\begin{array}{l}\text { Corre- } \\
\text { sponding } \\
\text { lymph }\end{array}$ & $\begin{array}{l}\text { Lowest } \\
\text { blood } \\
\text { count }\end{array}$ & $\begin{array}{l}\text { Corre- } \\
\text { sponding } \\
\text { lymph }\end{array}$ & $\begin{array}{c}\text { Lowest } \\
\text { blood } \\
\text { count }\end{array}$ & $\begin{array}{l}\text { Corre- } \\
\text { sponding } \\
\text { lymph }\end{array}$ & $\begin{array}{c}\text { Lowest } \\
\text { blood } \\
\text { count }\end{array}$ & $\begin{array}{l}\text { Corre- } \\
\text { sponding } \\
\text { lymph }\end{array}$ & $\begin{array}{c}\text { Lowest } \\
\text { blood } \\
\text { count }\end{array}$ & $\begin{array}{l}\text { Corre- } \\
\text { sponding } \\
\text { lymph }\end{array}$ & $\begin{array}{l}\text { Lowest } \\
\text { blood } \\
\text { count }\end{array}$ \\
\hline $\begin{array}{l}\text { RBC } \\
\text { Platelets } \\
\text { WBC } \\
\text { Differentials in per cent : } \\
\text { PMN } \\
\text { Meta } \\
\text { Myl } \\
\text { PME } \\
\text { Lymphs: } \\
\text { small } \\
\text { young } \\
\text { Mono } \\
\text { Others }\end{array}$ & $\begin{array}{r}132,500 \\
2,000 \\
4,000\end{array}$ & $\begin{array}{r}2,630,000 \\
25,000 \\
25,000\end{array}$ & $\begin{array}{r}6,300 \\
4,000 \\
17,000\end{array}$ & $\begin{array}{r}3,000,000 \\
90,000 \\
121,000 \\
2\end{array}$ & $\begin{array}{r}7,900,000 \\
55,000 \\
2,500 \\
4\end{array}$ & $\begin{array}{r}4,400,000 \\
75,000 \\
2,100 \\
20 \\
1 \\
79\end{array}$ & $\begin{array}{r}245,000 \\
45,000 \\
22,700\end{array}$ & $\begin{array}{r}3,110,000 \\
75,000 \\
23,800 \\
28 \\
3 \\
3\end{array}$ & $\begin{array}{r}5,000 \\
5,000 \\
210\end{array}$ & $\begin{array}{r}4,030,000 \\
85,000 \\
1,900\end{array}$ \\
\hline
\end{tabular}

after the left thoracic duct had been ligated did not significantly alter the circulating lymphocyte count.

Cellular characteristics. In general the leukocyte counts in lymph and venous blood in the living patient were the same as found in the post mortem studies. The peripheral blood leukocyte count in one patient with chronic lymphocytic leukemia (FLU) varied from 121,000 to 166,000 per cmm., and the comparable leukocyte counts in the lymph were 17,800 to 40,600 per $\mathrm{cmm}$. In another pa- 
TABLE II-Continued

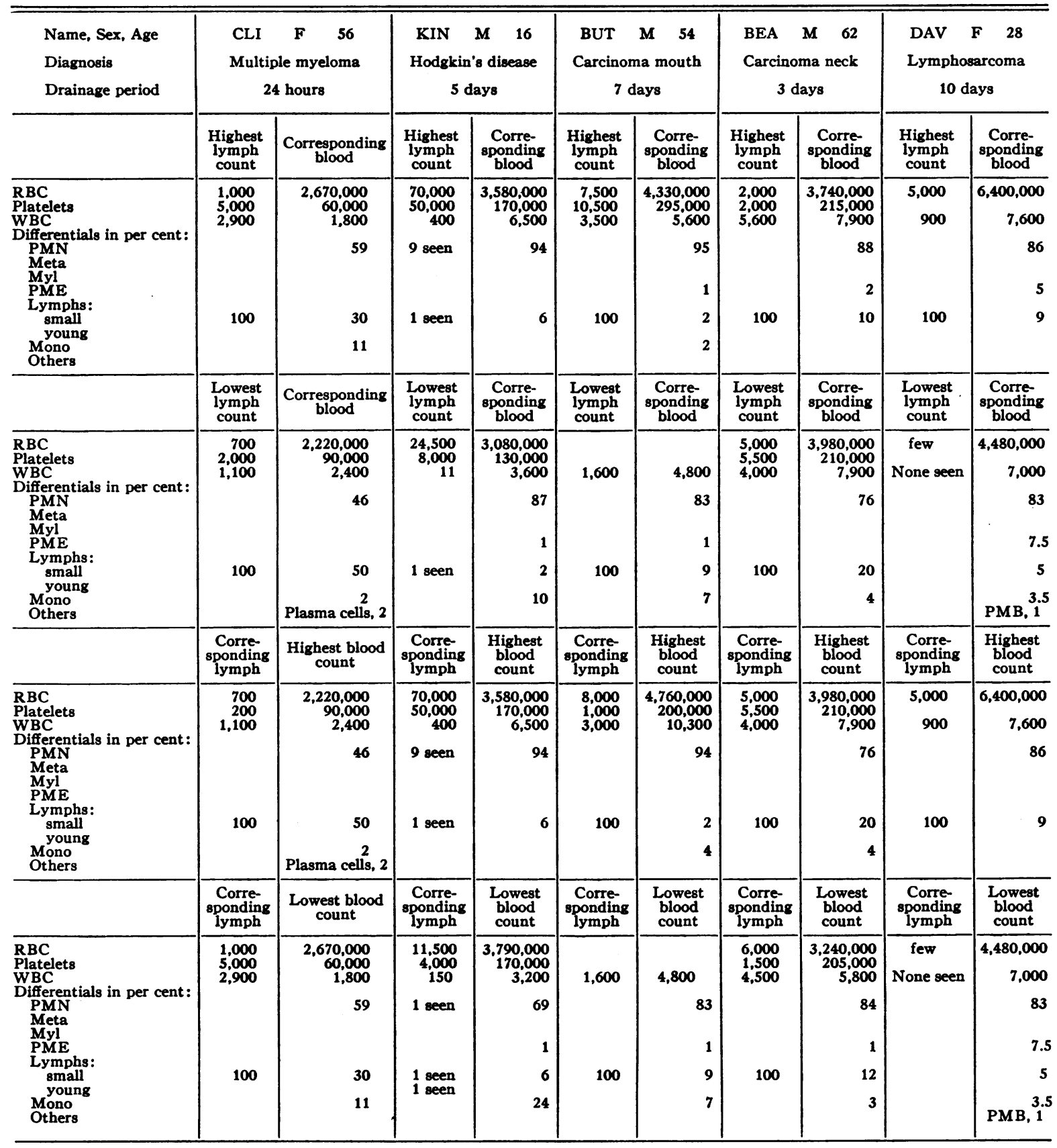

tient who had the same disease (ELM) the peripheral blood leukocyte number fluctuated between 25,000 and 49,000 per $\mathrm{cmm}$., while that in the lymph was found to be 4,200 to 6,200 per $\mathrm{cmm}$. The differential leukocyte counts showed smaller total numbers of lymphocytes in the lymph than in the blood in both cases (Table II).
On two occasions, the leukocyte level of the lymph initially exceeded that found in the venous blood. In one patient (KIR) with subleukemic lymphocytic leukemia, except for the first 24 hours, the leukocyte contents of the lymph and blood both varied considerably but in general were approximately the same (Figure 3). Similarly, in another 
TABLE III

Calculated total leukocyte flow from the thoracic duct in six patients compared to leukocyte number in the peripheral blood

\begin{tabular}{|c|c|c|c|c|c|c|c|c|}
\hline \multirow[b]{2}{*}{ Patient } & \multirow[b]{2}{*}{ Diagnosis } & \multirow{2}{*}{$\begin{array}{l}\text { Period } \\
\text { of flow }\end{array}$} & \multirow{2}{*}{$\begin{array}{l}\text { Flow per } \\
24 \text { hours } \\
\text { ml. }\end{array}$} & \multicolumn{2}{|c|}{$\begin{array}{l}\text { Average leukocyte } \\
\text { count per cmm. }\end{array}$} & \multirow{2}{*}{$\begin{array}{l}\text { Total leukocyte } \\
\text { flow per } 24 \text { hours } \\
\text { in the lymph }\end{array}$} & \multirow{2}{*}{$\begin{array}{c}\text { Body } \\
\text { weight } \\
\text { in } \mathbf{K} \mathbf{g} .\end{array}$} & \multirow{2}{*}{$\begin{array}{c}\text { Total leukocyte } \\
\text { number in } \\
\text { peripheral bloodt }\end{array}$} \\
\hline & & & & In lymph & In blood & & & \\
\hline $\begin{array}{l}\text { FLU } \\
\text { ELM } \\
\text { KIR } \\
\text { RAL } \\
\text { KIN } \\
\text { HAL }\end{array}$ & $\begin{array}{l}\text { Lymphatic leukemia } \\
\text { Lymphatic leukemia* } \\
\text { Lymphatic leukemia } \\
\text { Myeloblastic leukemia } \\
\text { Hodgkin's disease } \\
\text { Multiple myeloma }\end{array}$ & $\begin{array}{l}2 \text { days } \\
6 \text { hours } \\
10 \text { days } \\
2 \text { days } \\
3 \text { days } \\
12 \text { days }\end{array}$ & $\begin{array}{r}1,100 \\
900 \\
2,000 \\
1,000 \\
475 \\
800\end{array}$ & $\begin{array}{r}25,500 \\
4,800 \\
5,400 \\
19,500 \\
200 \\
2,100\end{array}$ & $\begin{array}{r}135,000 \\
38,000 \\
6,000 \\
33,500 \\
5,500 \\
3,500\end{array}$ & $\begin{array}{r}28.1 \times 10^{9} \\
4.3 \times 10^{9} \\
10.8 \times 10^{9} \\
19.5 \times 10^{9} \\
9.5 \times 10^{7} \\
1.7 \times 10^{9}\end{array}$ & $\begin{array}{l}59.5 \\
49.9 \\
68.0 \\
78.5 \\
48.5 \\
59.0\end{array}$ & $\begin{array}{l}56.2 \times 10^{10} \\
13.3 \times 10^{10} \\
28.5 \times 10^{9} \\
18.4 \times 10^{10} \\
18.7 \times 10^{9} \\
14.5 \times 10^{9}\end{array}$ \\
\hline
\end{tabular}

* Right thoracic duct-major lymphatics in the vicinity of the left jugular-subclavian junction had been ligated 48 hours previously.

t Calculated from blood volume estimated at 7 per cent of body weight.

patient (RAL), a 16-year-old boy with a fulminant myeloblastic leukemia associated with chloromatous tumor formation, the cells in the lymph were predominantly small mature lymphocytes which had no consistent numerical relationship to either the total number or differential leukocyte count in the peripheral blood.

The leukocyte content of the thoracic duct lymph in the non-leukemic patients in this study varied from 210 to 5,600 per $\mathrm{cmm}$. In three patients with leukemia the lymph leukocyte count was within the normal limits. In one patient (FLU) it was slightly higher than the upper limits of that reported for normal man (3). The lymph count in these four leukemic patients was approximately 10 to 100 per cent of that in the peripheral blood.

Chemical characteristics. Biochemical studies of simultaneously obtained lymph and venous blood in vivo were done on six patients. In four patients, daily or twice-daily samples were studied for 2 to 11 consecutive days (Table IV). The chemical constituents of the lymph and blood remained remarkably constant from day to day during the period of drainage. The globulin content of blood consistently exceeded that of the lymph in all patients and while the albumin content of the blood often exceeded that in the lymph the difference was neither as great nor as constant as that of the globulin (Table V). The total cholesterol content of blood was markedly higher than that in lymph, due primarily to the esterified fraction. The alkaline phosphatase and thymol turbidity determinations of the lymph were found to be 7 and 12 times higher respectively than that of the blood in one patient; in another patient the alkaline phosphatase values for blood and lymph were equal (Table V). The glucose content of lymph in one instance was significantly higher than that of blood.

There was no alteration in the clinical or hematological status, either exacerbation or improvement, in any patient following the procedure.

\section{DISCUSSION}

The leukocyte count in the thoracic duct in normal man varies from 2,000 to 20,000 per cmm. (3), consisting almost totally of lymphocytes (Figure 5). This is about 2 to 10 times the number of lymphocytes that can be found per cubic millimeter at any one time in the peripheral blood. The thoracic duct lymph in the normal subject is reported to flow between 1,500 and 2,200 cc. in each 24 hours which calculates to a delivery of approximately $35 \times 10^{\circ}$ cells per 24 hours into the peripheral circulation $(3,9)$. Since only onethird of this number can be accounted for in the peripheral blood, it has been assumed that the lymphocyte is replaced three times daily and that the intravascular life span of the lymphocyte can be calculated therefrom $(8,10,11)$. Calculations of life span of lymphocytes in the peripheral circulation by this method are based upon the premise of a single securely closed circulation consisting of the flow of lymphocytes from the production site through the thoracic duct into the blood and thence to destruction. There is no consideration of rapid removal by sequestration (12), recirculation in some organ (13), or return of lymphocytes from the peripheral blood back into the lymphatic system (14). If such calculations are valid (and there are many reasons to doubt it) (10), the life span of the lymphocytes in most of these leukemic patients would be expected to be longer than in the 


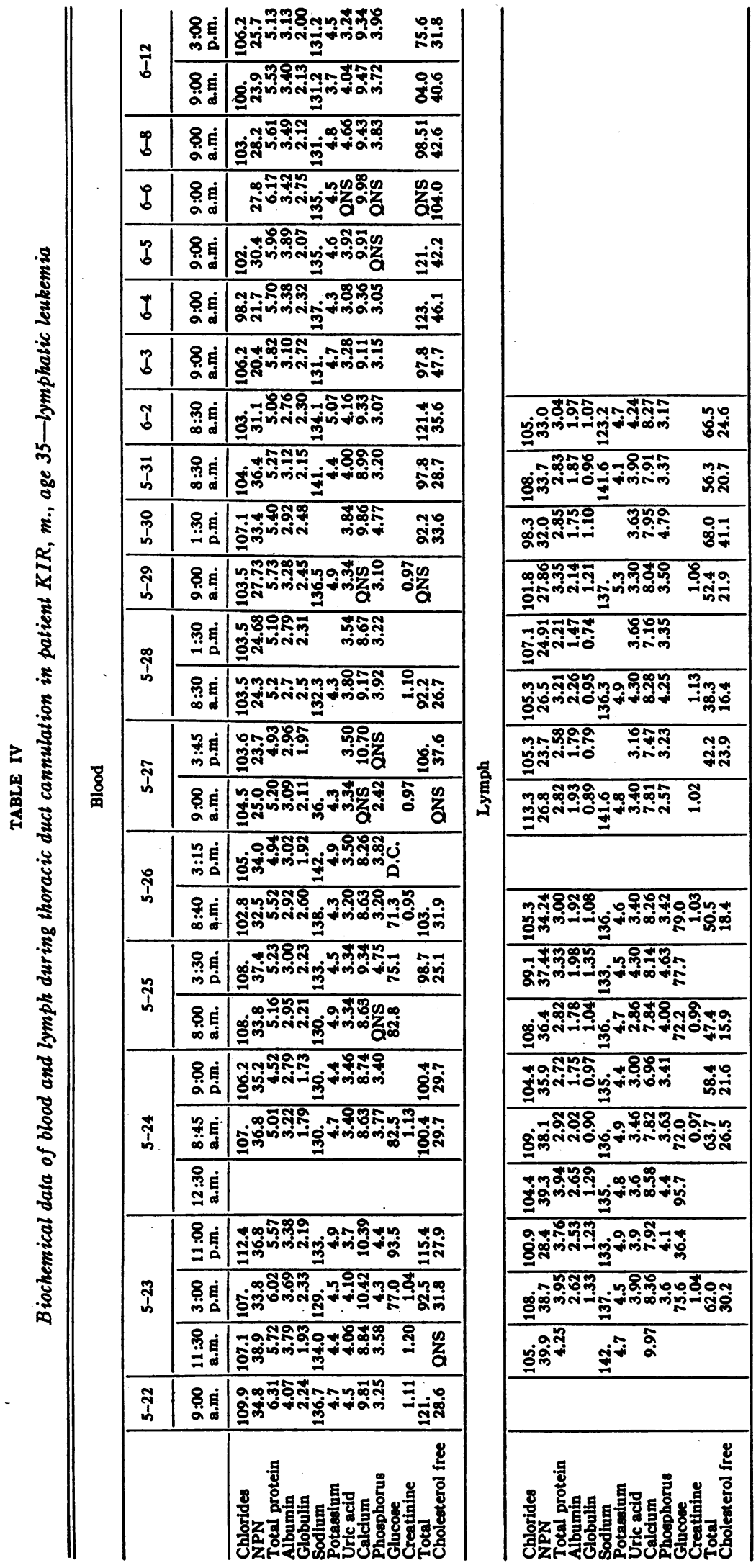




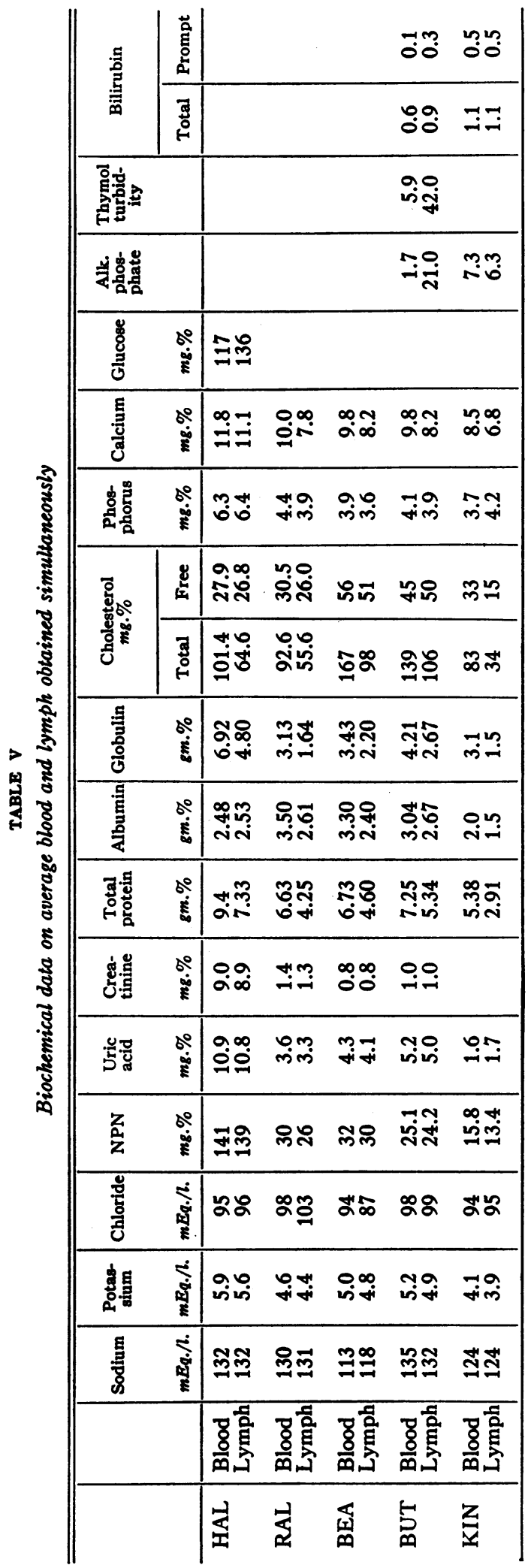



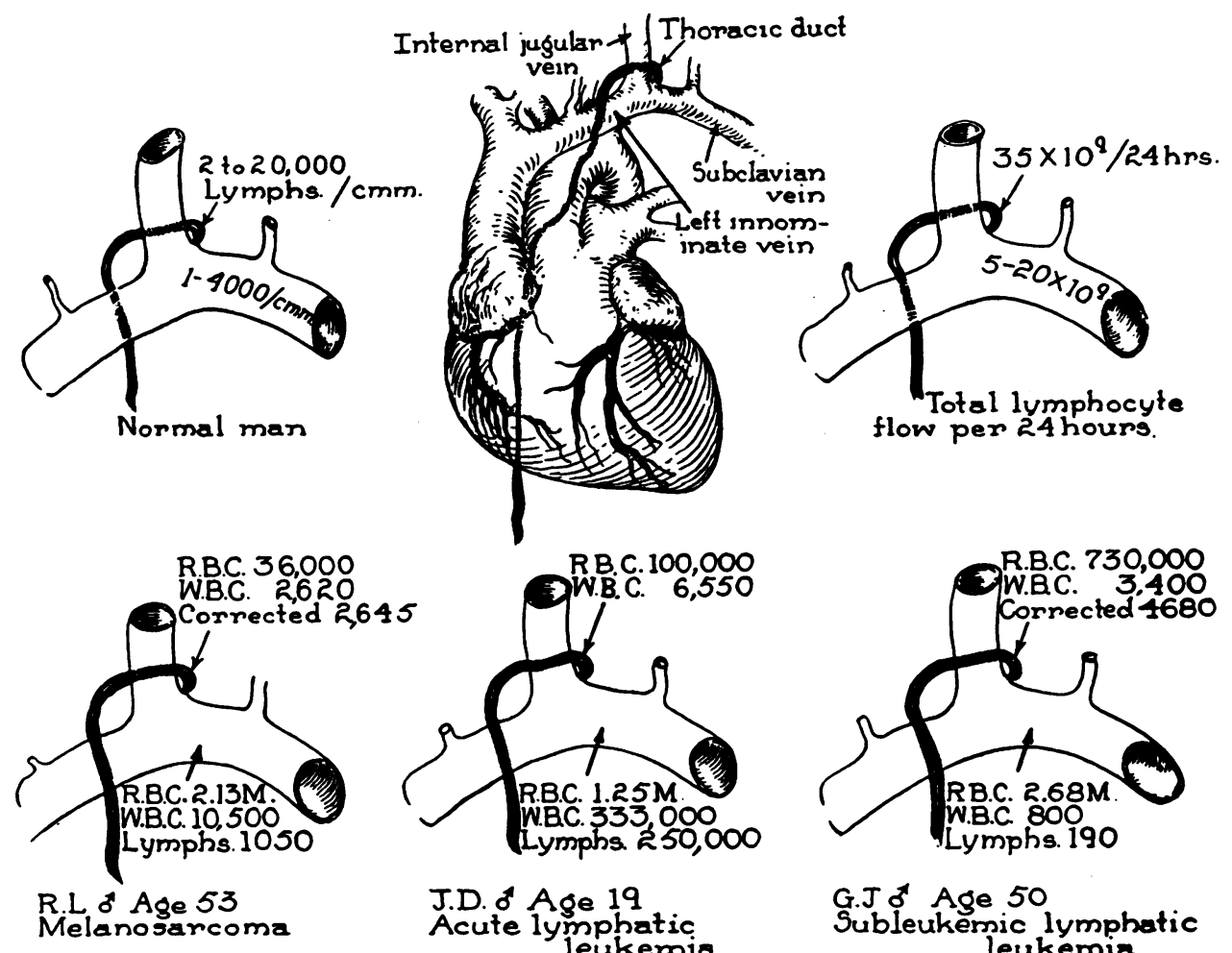

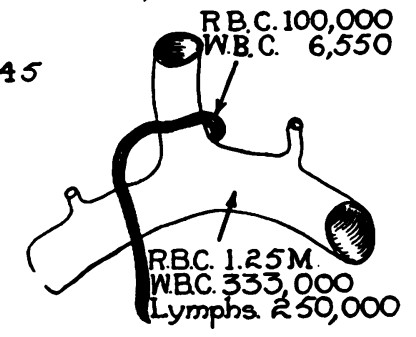

J.D. of Age 19 Acute lymphatic

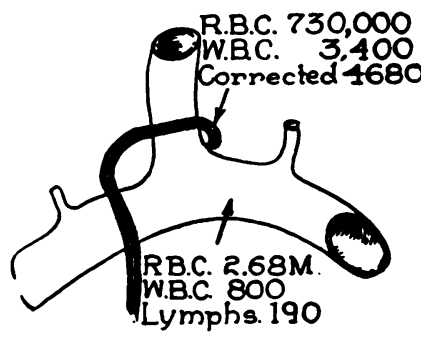

G.J ot Age 50 Subleukemic lymphatic

Fig. 5. Schematic Representation of Normal Lymphocyte Flow as Compared with that Found in a Non-leukemic Patient, and Two Patients with Lymphatic Leukemia, One with a High Peripheral Blood Leukocyte Count and One with a Leukopenia

The normal flow of lymph through the thoracic duct in man is estimated at approximately $\mathbf{3 5}$ billion lymphocytes per 24 hours. The duct lymphocyte counts in the three patients are approximately the same despite marked differences in the peripheral blood. The corrected counts are those caused by possible dilution with peripheral blood and show little change.

non-leukemic individual $(15,16)$. This would suggest some defect in the normal destruction or removal of the lymphocyte in the leukemic patient which would be reflected in a longer than normal life span in the intravascular circulation. This prolongation of life of the circulating lymphocyte may reside within the properties of the cell (17), the host or both.

In dogs, rabbits and cats the ligation of both right and left thoracic ducts results in a prompt fall in the peripheral blood lymphocyte number $(18,19)$. Similar results have been obtained by diverting the lymph flow by thoracic duct cannulation $(20,21,22)$. There was no significant fall in circulating lymphocyte number in the two day period of drainage in patient ELM in whom the right thoracic duct was cannulated after the major lymphatics in the left neck had been previously ligated. This would suggest that the life span of the lymphocytes in this patient with lymphatic leukemia was longer than the two days of drainage period or that his major portal of entry of lymphocytes was from a site other than the thoracic duct.

Approximately 5 per cent of all the cells in the lymph in these studies were found to be lymphoblasts which are rarely seen in the circulating blood in the normal individual. This absence of lymphoblasts suggests either a most rapid change within the blood to a small lymphocyte or prompt removal from the peripheral circulation. Similarly, there is a larger percentage of intermediatesized lymphocytes in the lymph than are found circulating in normal man. It should be noted that the thoracic duct empties just proximal to the pulmonary circulation. Attempts to detect any increases in lymphocyte number by venous catheter sampling at or proximal to the thoracic duct opening met uniformly with failure (12). In the 
patients with granulocytic and lymphocytic leukemia, granulocytes were found in considerable numbers in the lymph.

Significant numbers of erythrocytes in the lymph were present only in patients with the leukemias and, in general, reflected the hemorrhagic status of the patient. In those leukemic patients in whom transfusions were given to support a falling blood hemoglobin level, the erythrocyte count in the lymph also rose, particularly if there was little or no improvement of the hemorrhagic component. The factor of an increased permeability of the lymphatics or incompetent vein-duct valves in the leukemic patient also must be strongly entertained.

The data indicate that the number of leukocytes in the thoracic duct lymph in the patients studied usually was materially less than that of venous blood. Of particular significance was this finding in patients with lymphocytic leukemia with either high or low leukocyte counts in the peripheral blood. Similar findings occurred in one patient with myeloblastic leukemia. The non-leukemic patients in this study had fewer leukocytes in the lymph than reported for normal individuals (3, 4). The daily total volume of lymph flowing in the leukemic patients did not exceed that reported in normal subjects (3). Consequently, the total number of leukocytes entering the peripheral blood daily via the thoracic duct in the four leukemic cases in whom accurate lymph flow values were obtained did not exceed 35 billion leukocytes, the value reported by Drinker and Yoffey (3), to be entering the circulation in the normal subject.

The average number of leukocytes in the lymph of eight patients with lymphocytic leukemia, taking the highest count, was 64,600 per $\mathrm{cmm}$. while the peripheral blood at the same time averaged 260,900 . The ratio of the counts, lymph to blood, was 1 to 4 . Six of these eight patients had lymph leukocyte counts exceeding the 2 to 20,000 per cmm. value reported by Drinker and Yoffey (3). Similarly, in seven non-leukemic patients the highest lymph count averaged 2,760 with the corresponding blood count averaging 6,070-a ratio of 1 to 2.3 .

In his original description of leukemia (23), Virchow concluded that leukemia was a disease of overproduction of the leukocytes and shortly thereafter expanded this impression to include the thoracic duct as the route by which the excess number of cells entered the circulation (24). Since this time, many other investigators have accumulated other information which supports the concept of overproduction of leukocytes. These findings are not in accord with this concept of leukemia and create a valid doubt that the thoracic duct is the major pathway of delivery of the excessive numbers of leukocytes into the peripheral blood in all leukemias, or that the leukocytosis in the leukemic patients studied is always a result of an increased production of leukocytes delivered by the thoracic duct route. The possibility of other portals of entry for these cells have not been excluded in these studies. Also, the good possibility remains that there may be a constant variation between rates of production, delivery and removal which may make it fortuitous consistently to fail to obtain evidence of delivery of excessive numbers of cells via any route.

It should be emphasized that these data were obtained on relatively few patients and therefore may not thoroughly represent the variation in lymphocyte flow in man (9). While the numbers of leukocytes obtained in the thoracic duct lymph probably represent the minimum, since in all but one case only the left thoracic duct was cannulated, the avoidance of general anesthesia and the magnitude of the discrepancies between the findings in the lymph and venous blood support these interpretations. The further multiplication of cells by rapid division in the circulation after they leave the thoracic duct requires consideration before any further conclusions can be drawn.

\section{SUM MARY}

1. Thoracic duct lymph was collected from 11 cadavers within one hour after death, and from 10 patients during life for continuous periods of 2 to 13 days.

2. The leukocyte count of the lymph varied from 210 to 5,600 leukocytes per cmm. in six non-leukemic patients studied during life.

The lymphocyte count in lymph in the leukemic patients during life usually did not exceed the lymphocyte count in the venous blood. In one patient with subleukemic lymphocytic leukemia for the first of 11 days the leukocyte count of the lymph exceeded that of the peripheral blood. 
3. The findings of the studies conducted post mortem in 11 patients, 10 of whom had leukemia, were similar to those obtained in vivo. In three patients, the lymph leukocyte count exceeded or equalled that in the blood. In the remaining eight patients, six of whom had lymphocytic leukemia, the peripheral blood leukocyte number exceeded that found in the lymph.

4. The erythrocyte number in the thoracic duct lymph obtained from patients with the leukemias was considerable, ranging up to 1.5 million per $\mathrm{cmm}$. The erythrocyte count in the lymph of the non-leukemic patients was generally insignificant. The lymph platelet number varied considerably in both groups $(1,000$ to 95,000 per $\mathrm{cmm}$.) and never rose to the level found in the venous blood.

5. The chemical composition of thoracic duct lymph closely approximated that of blood plasma with slightly reduced values for albumin and globulin. The antithrombin and prothrombin content of thoracic duct lymph in two patients in whom it was measured was comparable to that found in the venous blood. The cholesterol ester content of the lymph exceeded that of blood.

6. No beneficial or deleterious effects of the procedure were observed on the clinical or hematological course of the patients studied.

\section{ACKNOWLEDGMENTS}

The authors wish to acknowledge the assistance of Dr. W. O. Reinhardt, Miss Marjorie Brown, Mrs. Oma Mitchell and Mrs. Anna Lance.

\section{REFERENCES}

1. Drinker, C. K., and Field, M. E., Lymphatics, Lymph and. Tissue Fluid. Williams \& Wilkins, Baltimore, 1933.

2. Blalock, A., Robinson, C. S., Cunningham, R. S., and Gray, M. E., Experimental studies on lymphatic blockage. Arch. Surg., 1937, 34, 1049.

3 .Drinker, C. K., and Yoffey, J. M., Lymphatics, Lymph and Lymphoid Tissue. Harvard University Press, Cambridge, Mass., 1941.

4. Haedicke, J., Ueber polynukleäre neutrophile Lymphzellen (Eln Beitrag zur Lösung der Frage nach der Abstammung der Farblosen Blutzellen). Folia haematol., 1906, 3, 527.

5. Bainbridge, F. A., The post-mortem flow of lymph. J. Physiol., 1906, 34, 275.

6. Rouviere, H., and Valette, G., Physiologie du systeme lymphatique. "Formation de la lymphe, circulation lymphatique normale et pathologique." Masson et Cie, Paris, 1937. Cited in (4).
7. Bierman, H. R., Gilfillan, R. S., Kelly, K. H., Byron, R. L., Jr., and Freeman, N., Cannulation of the thoracic duct in man. Proc. Amer. Fed. Clin. Res., May 1951.

8. Yoffey, J. M., The quantitative study of lymphocyte production. J. Anat., 1932-1933, 67, 250.

9. Yoffey, J. M., Variation in lymphocyte production. J. Anat., 1935-1936, 70, 507.

10. Ehrich, W. E., The role of the lymphocyte in the circulation of the lymph. Ann. New York Acad. Sc., 1945-1946, 46, 823.

11. Adams, W. S., Saunders, R. H., and Lawrence, J. S., Output of lymphocytes in cats including studies on thoracic duct lymph and peripheral blood. Am. J. Physiol., 1945, 144, 297.

12. Lanman, J. T., Bierman, H. R., and Byron, R. L., Jr., Transfusion of leukemic leukocytes in man: hematologic and physiologic changes. Blood, 1950, 5, 1099.

13. Bierman, H. R., Some principles underlying the pathological physiology of the leukemias in man. Proc. Second National Cancer Conference (sponsored jointly by the American Cancer Society and the National Cancer Institute, Cincinnati, March 1952), in press.

14. Clark, E. R., and Clark, E. L., Observations on living mammalian lymphatic capillaries-their relation to the blood vessels. Am. J. Anat., 1936-1937, 60, 253.

15. Kline, D. L., and Cliffton, E. E., The life span of leucocytes in the human. Science, 1952, 115, 9.

16. Osgood, E. E., Tivey, H., Davison, K. B., Seaman, A. J., and $\mathrm{Li}, \mathrm{J}$. G., The relative rates of formation of new leukocytes in patients with acute and chronic leukemias measured by the uptake of radioactive phosphorus in the isolated desoxyribosenucleic acid. Cancer, 1952, 5, 331.

17. Morrow, P. L., Bierman, H. R., and Jenkins, R., Effect of ultrasonic vibration on the formed elements of blood from normal and leukemic subjects. J. Nat. Cancer Inst., 1950, 10, 843.

18. Bunting, C. H., and Huston, J., Fate of the lymphocyte. J. Exper. Med., 1921, 33, 593.

19. Lee, F. C., Changes in the number of small lymphocytes of the blood following ligation of the thoracic duct. J. Exper. Med., 1922, 36, 247.

20. Biedl, A., and von Decastello, A., Ueber Aenderungen des Blutbildes nach Unterbrechung des Lymphzuflusses. Arch. f. d. ges. Physiol., 1901, 86, 259.

21. Banti, G., Sull'ufficio degli - organi linfopoietico ed emopoietici nella genesi dei globuli bianchi del sangue. Cited in (14). Arch. fisiol., 1903-4, 1, 241.

22. Kindwall, J. A., A supra-vital study of the cells in the lymph stream of the rabbit. Bull. Johns Hopkins Hosp., 1927, 40, 39.

23. Virchow, R. L., (Weisses Blut). Neue Notizen a.d. Geb. d. Nat. Heilk. Weimar, 1845, 36, 151.

24. Virchow, R., Cellular pathology as based upon physiological and pathological histology. De Witt Publisher, New York, 1858, pp. 204-205. 